\title{
PYRAZOLINES AS POTENT ANTITUBERCULAR AND CYTOTOXIC AGENTS
}

\author{
ISHWAR BHAT K, ABHISHEK KUMAR*
}

Department of Pharmaceutical Chemistry, NGSM Institute of Pharmaceutical Sciences, Nitte University, Paneer, Deralakatte, Mangalore, Karnataka, India. Email: abhi12bunty@gmail.com

Received: 28 January 2016, Revised and Accepted: 27 March 2017

ABSTRACT

Objective: Pyrazolines are known to exhibit different biological and pharmacological properties such as anticancer, antibacterial, antifungal and antitubercular activities. Chalcones with an enone group between two aromatic rings exhibit remarkable pharmacological activities such as antiinflammatory, antibacterial, antitumor, antifungal, and antimalarial activity. A series of pyrazolines from chalcones have been synthesized and evaluated for antitubercular and cytotoxic activity studies.

Methods: Chalcones [3-substituted phenyl-1-(p-tolyl)prop-2-en-1-one] were synthesized from various substituted aldehydes and 4-methyl acetophenone and cyclized into pyrazolines [5-substituted phenyl-3-(p-tolyl)-4,5-dihydro-1H-pyrazole] using hydrazine hydrate. Antitubercular and cytotoxic activity studies were carried out.

Results: Antitubercular and cytotoxic activity studies of synthesized pyrazoline revealed that some compounds have showed promising activity.

Conclusion: The observed results proved that pyrazolines are found to be interesting lead molecules for further synthesis as antitubercular and cytotoxic agents.

Keywords: Chalcones, Pyrazoline, Antitubercular activity, Cytotoxic activity.

(C) 2017 The Authors. Published by Innovare Academic Sciences Pvt Ltd. This is an open access article under the CC BY license (http://creativecommons. org/licenses/by/4. 0/) DOI: http://dx.doi.org/10.22159/ajpcr.2017.v10i6.17344

\section{INTRODUCTION}

Nitrogen-containing heterocyclic compounds such as pyrazolines have received remarkable attention in the recent years due to their diverse pharmacological and biological activities such as antitubercular [1], antidepressant [2], anticonvulsant [3], antitumor [4], antiinflammatory [5], analgesic [6], antibacterial [7], and anticancer [8]. The intermediate used are substituted chalcones derived from various substituted aldehydes and ketones which are known for their anticancer [9], antioxidant [10], analgesic [11], anti-inflammatory [12], and antimalarial [13] activities. Based on the observations, it was contemplated to synthesize a novel series pyrazoline derivatives derived from substituted chalcones. All the synthesized compounds have been screened for their in vitro antitubercular and cytotoxic activity studies.

\section{METHODS}

All the chemicals used such as 4-methyl acetophenone, substituted benzaldehydes, hydrazine hydrate, sodium hydroxide, ethanol, and glacial acetic acid used were of analytical grade. Melting points were determined by the capillary method and were uncorrected. The infrared (IR) spectra were recorded by using Shimadzu Perkin Ekuner-8201 Pc IR spectrometer using a thin film on potassium bromide pellets techniques, and absorption frequencies are expressed in $\mathrm{cm}^{-1}$. The ${ }^{1} \mathrm{H}$ Nuclear magnetic resonance (NMR) spectra were recorded on Bruker Avance 11400 NMR spectrometer using deuterochloroform and DMSO as solvent. Chemical shift values were reported as values in ppm relative to tetramethylsilane $(\delta=0)$ as an internal standard. Mass spectra were recorded on JEOL SX-102/DA-6000 mass spectrometer using Argon/Xenon ( $6 \mathrm{kV}, 10 \mathrm{Ma}$ ) as the FAB gas. The purity of the compounds was checked on silica gel coated plates by using ethyl acetate: chloroform (1:9) as a solvent and observed in ultraviolet light.

\section{General procedure}

Synthesis of 3-substituted phenyl-1-(p-tolyl)prop-2-en-1-one [14] A mixture of 4-methyl acetophenone $(0.01 \mathrm{~mol})$ and substituted benzaldehydes $(0.01 \mathrm{~mol})$ in ethanol $(20 \mathrm{ml})$ was stirred for $24 \mathrm{hrs}$ in the presence of $20 \% \mathrm{NaOH}(4-5 \mathrm{ml})$. The mixture was poured into crushed ice and acidified with $5 \% \mathrm{HCl}$. The product obtained was filtered, washed with water, and recrystallized from ethanol.

Synthesis of 5-substituted phenyl-3-(p-tolyl)-4,5-dihydro-1Hpyrazole [15]

A mixture of substituted chalcones $(0.01 \mathrm{~mol})$ in $20 \mathrm{ml}$ of glacial acetic acid and hydrazine hydrate $(0.01 \mathrm{~mol})$ were added and refluxed for 16-20 hrs. After the completion of the reaction, the reaction mixture was poured into $250 \mathrm{ml}$ of ice cold water. The solid separated was filtered, washed with cold water, dried, and recrystallized by using ethanol/chloroform. The purity of the compound was checked by using ethyl acetate: chloroform (1:9) as a solvent for TLC.

\section{Spectral data}

5-(4-chlorophenyl)-3-(p-tolyl)-4,5-dihydro-1H-pyrazole ( $\left.P Z_{1}\right)$

IR (KBr) cm ${ }^{-1}: 1641$ (C=N str), 2921 (C-H aliphatic), 3018(C-H aromatic), 730 (C-Cl str), 1550 (C=C str), 1324(C-N str), 3258(N-H str); ${ }^{1} \mathrm{H}$ NMR $(\delta$ ppm): 2.3 (s, $3 \mathrm{H}$ of $\mathrm{CH}_{3}$ ), 7.2-7.5 (m, 9H, Ar-H), 3.3-3.6 (dd, $\mathrm{IH}$ of $\mathrm{H}_{\mathrm{a}}$ ), 3.6-3.9 (dd, $\mathrm{IH}$ of $\mathrm{H}_{\mathrm{b}}$ ), 5.3-5.8 (dd, $\mathrm{IH}$ of $\mathrm{H}_{\mathrm{c}}$ ), 7.7 (s, $1 \mathrm{H}$ of NH); MS: m/z $271(\mathrm{M}+1)$.

\section{3,5-di-p-tolyl-4,5-dihydro-1H-pyrazole $\left(\mathrm{PZ}_{2}\right)$}

IR (KBr) cm${ }^{-1}: 1639$ (C=N str), 2918(C-H aliphatic), 3015(C-H aromatic), 1545 (C=C str), 1318 (C-N str); ${ }^{1} \mathrm{H}$ NMR $(\delta$ ppm $): 2.2\left(\mathrm{~s}, 3 \mathrm{H}\right.$ of $\left.\mathrm{CH}_{3}\right), 7.1-$ 7.5 (m, 9H, Ar-H), 3.4-3.7(dd, IH of $\mathrm{H}_{\mathrm{a}}$ ), 3.7-4.0 (dd, $\mathrm{IH}_{\text {of }} \mathrm{H}_{\mathrm{b}}$ ), 5.4-5.8 (dd, IH of $\left.\mathrm{H}_{\mathrm{c}}\right), 7.6(\mathrm{~s}, 1 \mathrm{H}$ of $\mathrm{NH})$; MS: $\mathrm{m} / \mathrm{z} 250\left(\mathrm{M}^{+}\right)$.

\section{5-(4-nitrophenyl)- 3-(p-tolyl)- 4,5-dihydro-1H-pyrazole $\left(P Z_{3}\right)$}

IR (KBr) cm ${ }^{-1}: \quad 1648(\mathrm{C}=\mathrm{N}$ str), 2914(C-H aliphatic), 3024(C-H aromatic str), $1540\left(\mathrm{C}=\mathrm{C}\right.$ str), $1314\left(\mathrm{C}-\mathrm{N}\right.$ str), $1428\left(\mathrm{Ar}^{-\mathrm{NO}_{2}} \mathrm{str}\right) ;{ }^{1} \mathrm{H}$ NMR $(\delta \mathrm{ppm}): 2.1\left(\mathrm{~s}, 3 \mathrm{H}\right.$ of $\left.\mathrm{CH}_{3}\right), 7.2-7.6(\mathrm{~m}, 9 \mathrm{H}, \mathrm{Ar}-\mathrm{H}), 3.5-3.7$ (dd, $\mathrm{IH}$ of $\mathrm{H}_{\mathrm{a}}$ ), 


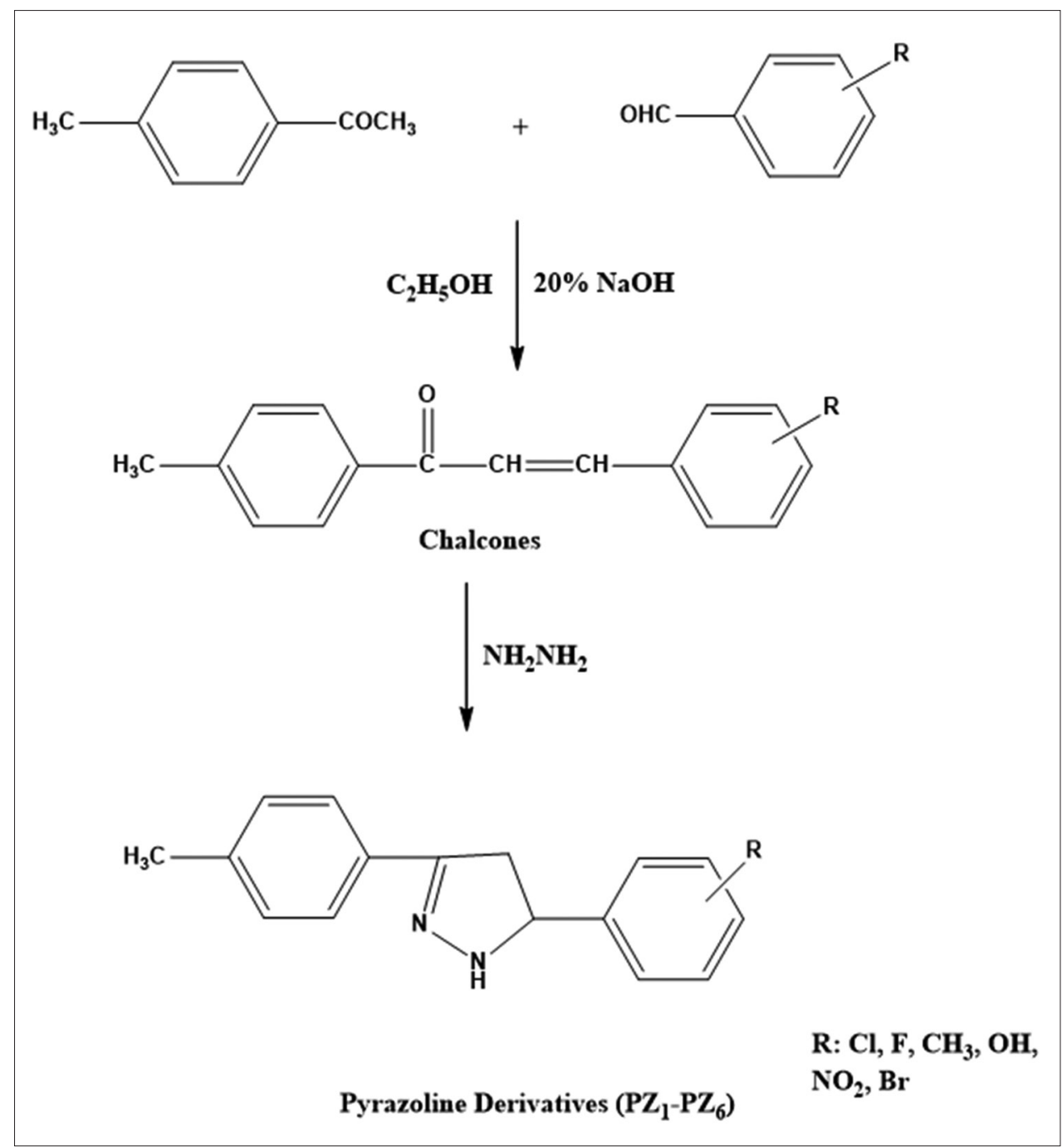

Fig. 1: Scheme for pyrazoline derivatives

Table 1: Physical data of the synthesized compounds

\begin{tabular}{llllll}
\hline Compound code & $\mathbf{R}$ & Molecule weight & $\mathbf{M . P}^{\circ} \mathbf{C}$ & Physical state & \% yield \\
\hline $\mathrm{PZ}_{1}$ & $4-\mathrm{Cl}$ & 270 & $136-138$ & White crystals & 72 \\
$\mathrm{PZ}_{2}$ & $4-\mathrm{CH}_{3}$ & 250 & $92-94$ & White crystals & 71 \\
$\mathrm{PZ}_{3}$ & $4-\mathrm{NO}_{2}$ & 281 & $168-170$ & Yellow crystals & 69 \\
$\mathrm{PZ}_{4}$ & $4-\mathrm{OH}$ & 252 & $116-118$ & Brown crystals & 65 \\
$\mathrm{PZ}_{5}$ & $4-\mathrm{Br}$ & 301 & $176-178$ & Orange crystals & 74 \\
$\mathrm{PZ}_{6}$ & $4-\mathrm{F}$ & 254 & $152-154$ & White crystals & 73 \\
\hline
\end{tabular}

3.8-4.1 (dd, $\mathrm{IH}$ of $\mathrm{H}_{\mathrm{b}}$ ), 5.4-5.9 (dd, $\mathrm{IH}$ of $\mathrm{H}_{\mathrm{c}}$ ), $7.8(\mathrm{~s}, 1 \mathrm{H}$ of $\mathrm{NH}$ ); MS: m/z $281\left(\mathrm{M}^{+}\right)$.

Antitubercular activity using microplate alamar blue assay (MABA) [16]

The antimycobacterial activity of synthesized compounds was assessed against Mycobacterium tuberculosis using MABA. The 96 well plate received $10 \mu \mathrm{l}$ of the Middlebrook $7 \mathrm{H} 9$ broth and serial dilution of compounds were made directly on the plate. The final drug concentrations of the tested compounds were $0.2-100 \mu \mathrm{l} / \mathrm{ml}$ and standards used are INH. Plates were covered and sealed with parafilm and incubated at $37^{\circ} \mathrm{C}$ for 7 days. After this, $25 \mu$ of freshly prepared 1:1 mixture of Alamar blue reagent and $10 \%$ tween 80 was added to the plate and incubated for $24 \mathrm{hrs}$. The presence of blue color in the well indicated no bacterial growth and appearance of pink color indicated the growth. The minimum inhibitory concentration (MIC) was defined as lowest drug concentration which prevented the color change from blue to pink. The MIC data are given in Table 2. Compounds $\mathrm{PZ}_{1}, \mathrm{PZ}_{3}$, $\mathrm{PZ}_{4}, \mathrm{PZ}_{5}$, and $\mathrm{PZ}_{6}$ have shown significant antitubercular activity with MIC ranging from 7.5 to $18 \mu \mathrm{g} / \mathrm{ml}$.

\section{Cytotoxic activity}

All the test compounds were screened for cytotoxic activity against Ehrlich Ascites Carcinoma (EAC) cells. The tumor cells aspirated from the peritoneal cavity of tumor-bearing mice was washed thrice with normal saline and checked for viability using Trypan blue exclusion method [17]. The cell suspension (1 million cells in $0.1 \mathrm{ml}$ ) was added to tubes containing various concentrations of the test compounds and volume was made up to $1 \mathrm{ml}$ using phosphate buffered saline. Control tubes contained only cell suspension. The assay mixtures were incubated for $3 \mathrm{hrs}$, at $37^{\circ} \mathrm{C}$, and then, percent of dead cells were evaluated by trypan blue exclusion method. Compounds $\mathrm{PZ}_{1}, \mathrm{PZ}_{3}$, and $\mathrm{PZ}_{5}$ induced 
Table 2: Antitubercular activity of compounds $\left(\mathrm{PZ}_{1}-\mathrm{PZ}_{6}\right)$ by microplate alamar blue assay

\begin{tabular}{ll}
\hline Compounds & MIC in $\boldsymbol{\mu g} / \mathbf{m l}$ \\
\hline $\mathrm{PZ}_{1}$ & 7.5 \\
$\mathrm{PZ}_{2}$ & 40 \\
$\mathrm{PZ}_{3}$ & 10 \\
$\mathrm{PZ}_{4}$ & 18 \\
$\mathrm{PZ}_{5}$ & 17 \\
$\mathrm{PZ}_{6}$ & 15 \\
$\mathrm{INH}$ & 3.125 \\
\hline
\end{tabular}

MIC: Minimum inhibitory concentration

Table 3: Cytotoxic activity of compounds $\left(\mathrm{PZ}_{1}-\mathrm{PZ}_{6}\right)$ by Trypan blue exclusion method

\begin{tabular}{llllll}
\hline Compounds & \multicolumn{5}{l}{$\begin{array}{l}\text { Number of dead cells (\%) at different } \\
\text { concentrations }(\boldsymbol{\mu g} / \mathbf{m l})\end{array}$} \\
\cline { 2 - 6 } & $\mathbf{1 0}$ & $\mathbf{2 0}$ & $\mathbf{5 0}$ & $\mathbf{1 0 0}$ & $\mathbf{2 0 0}$ \\
\hline Control & - & - & - & - & - \\
$\mathrm{PZ}_{1}$ & 11 & 21 & 36 & 53 & 65 \\
$\mathrm{PZ}_{2}$ & 07 & 16 & 20 & 35 & 35 \\
$\mathrm{PZ}_{3}$ & 10 & 23 & 37 & 54 & 70 \\
$\mathrm{PZ}_{4}$ & 05 & 19 & 29 & 37 & 42 \\
$\mathrm{PZ}_{5}$ & 05 & 20 & 30 & 31 & 50 \\
$\mathrm{PZ}_{6}$ & 12 & 32 & 46 & 56 & 75 \\
5 -fluorouracil & 20 & 35 & 50 & 85 & 95 \\
\hline
\end{tabular}

the greatest effect on EAC cells with an activity more than $60 \%$ at a concentration of $200 \mu \mathrm{g} / \mathrm{ml}$. The results are summarized in Table 3 .

\section{RESULTS AND DISCUSSION}

\section{Antitubercular activity}

The test compounds were evaluated for their antitubercular activity against M. tuberculosis using MABA. A blue color in the well was interpreted as no bacterial growth, and pink color was scored as growth. This indicates that the test compound has potent antitubercular activity under in vitro condition. Compounds $\mathrm{PZ}_{1}, \mathrm{PZ}_{3}, \mathrm{PZ}_{4}, \mathrm{PZ}_{5}$, and $\mathrm{PZ}$ have shown significant antitubercular activity with MIC ranging from 7.5 to $18 \mu \mathrm{g} / \mathrm{ml}$ compared to the standard drug isoniazid. The presence of pyrazoline moiety with substitution and groups such as chloro, nitro, hydroxy, bromo, and fluoro resulted in significant antitubercular activity.

\section{Cytotoxic activity}

The test compounds were screened for their cytotoxic activity against EAC cells using trypan blue exclusion method. Compounds $\mathrm{PZ}_{1}, \mathrm{PZ}_{3}$, and $\mathrm{PZ}_{5}$ induced significant effect on EAC cells with an activity more than $60 \%$ at a concentration of $200 \mu \mathrm{g} / \mathrm{ml}$. The presence of pyrazoline moiety with electron withdrawing groups such as chloro, nitro, and bromo has accounted for their remarkable cytotoxic activity.

\section{CONCLUSION}

The study reports the successful synthesis of pyrazoline derivatives with moderate yields, and most of the synthesized compounds showed potent antitubercular and cytotoxic activities.

\section{ACKNOWLEDGMENT}

The authors are thankful to Nitte University for providing the necessary facilities to carry out this work. The authors are grateful to Head, SAIF, Panjab University, Chandigarh, for providing spectroscopic data and Amala Cancer Research Centre, Thrissur, for providing cytotoxic activity facilities.

\section{REFERENCES}

1. Ali MA, Yar MS, Kumar M, Pandian GS. Synthesis and antitubercular activity of substituted novel pyrazoline derivatives. Nat Prod Res 2007;21(7):575-9.

2. Palaska E, Erol D, Demirdamar R. Synthesis and antidepressant activities of some 1, 3, 5-triphenyl-2-pyrazolines. Eur J Med Chem 1996;31(1):43-7.

3. Bhandari S, Tripathi AC, Saraf SK. Novel 2-pyrazoline derivatives as potential anticonvulsant agents. Med Chem Res 2013;22(11):5290-6.

4. Amin KM, Eissa AA, Abou-Seri SM, Awadallah FM, Hassan GS. Synthesis and biological evaluation of novel coumarin-pyrazoline hybrids endowed with phenylsulfonyl moiety as antitumor agents. Eur J Med Chem 2013;60:187-98.

5. Malhotra P, Pattan S, Nikalje AP. Microwave assisted synthesis and anti-inflammatory activity of 3, 5-diaryl substituted-2-pyrazolines. Indian J Pharm Pharm Sci 2010;2(2):21-6.

6. Velmurugan V, Surya SP, Kalvikkarasi S, Shanmugapriya S, Vijay AM. Synthesis, characterization and evaluation of analgesic activity of 3 , 5-disubstituted pyrazoline derivatives. Indian J Pharm Pharm Sci 2012;4(2):189-91.

7. Hassan SY. Synthesis, antibacterial and antifungal activity of some new pyrazoline and pyrazole derivatives. Molecules 2013;18(3):2683-711.

8. Karabacak M, Altintop MD, Ibrahim Çiftçi H, Koga R, Otsuka M, Fujita M, et al. Synthesis and evaluation of new pyrazoline derivatives as potential anticancer agents. Molecules 2015;20(10):19066-84.

9. Syam S, Abdelwahab SI, Al-Mamary MA, Mohan S. Synthesis of chalcones with anticancer activities. Molecules 2012;17(6):6179-95.

10. Bandgar BP, Gawande SS, Bodade RG, Totre JV, Khobragade CN. Synthesis and biological evaluation of simple methoxylated chalcones as anticancer, anti-inflammatory and antioxidant agents. Bioorg Med Chem 2010;18(3):1364-70.

11. Heidari MR, Foroumadi A, Amirabadi A, Samzadeh-Kermani A, Azimzadeh BS, Eskandarizadeh A. Evaluation of anti-inflammatory and analgesic activity of a novel rigid 3, 4-dihydroxy chalcone in mice. Ann N Y Acad Sci 2009;1171:399-406.

12. Nowakowska Z. A review of anti-infective and anti-inflammatory chalcones. Eur J Med Chem 2007;42(2):125-37.

13. Tadigoppula N, Korthikunta V, Gupta S, Kancharla P, Khaliq T, Soni A, et al. Synthesis and insight into the structure-activity relationships of chalcones as antimalarial agents. J Med Chem 2013;56(1):31-45.

14. Kotra V, Ganapaty S, Adapa SR. Synthesis of a new series of quinolinyl chalcones as anticancer and anti-inflammatory agents. Indian J Chem 2011;41B:1109-16.

15. Chovatia YS, Gandhi SP, Gorde PL, Bagade SB. Synthesis and antibacterial activity of some pyrazoline derivatives. Orient J Chem 2010;26(1):275-8.

16. Louis KS, Siegel AC. Cell viability analysis using trypan blue: Manual and automated methods. Methods Mol Biol 2011;740:7-12.

17. Chauca JA, Palomino JC, Guerra H. Evaluation of the accuracy of the microplate Alamar Blue assay for rapid detection of MDR-TB in Peru. Int J Tuberc Lung Dis 2007;11(7):820-2. 